\title{
Investigation of Sodium Chloride Tolerance of Moringa (Moringa Oleifera Lam.) Transplants
}

\author{
Ayoub Zeyada Elhag*, Maha Hussien Abdalla \\ Department of Horticulture, College of Agricultural Studies, Sudan University of Science and Technology, Sudan \\ *Corresponding Author: zadhag@yahoo.com
}

Copyright $(C 2014$ Horizon Research Publishing All rights reserve.

\begin{abstract}
This study was conducted at the nursery of Department of Horticulture, College of Agricultural Studies, Sudan University of Science and Technology. Sodium chloride $(\mathrm{NaCl})$ tolerance of 2-months moringa transplants ( Moringa oleifera .Lam.) was investigated in plastic pots containing $0.0,0.2,0.4$ and $0.8 \% \mathrm{NaCl}(\mathrm{w} / \mathrm{w}$ of .soil) resembling $1.8,4,8$ and $16 \mathrm{dSm}^{-1}$ electrical conductivity (Ec) of the soil solution ), in a completely randomized design with four replications. The vegetative growth was evaluated as transplant height, number of leaves and root length. The concentrations of $\mathrm{Na}^{+}, \mathrm{K}^{+,} \mathrm{Ca}^{2+}$ and $\mathrm{Cl}^{-}$in the transplant parts (stem, leaves and roots) were also recorded Both shoot and root growth parameters were only slightly affected by the different $\mathrm{NaCl}$ concentrations. However, the stem height and number of leaves were significantly reduced $(30 \%$ and $40 \%$,respectively) by the highest $\mathrm{NaCl}$ concentration $(0.8 \%$ $\mathrm{NaCl}$ ). Mineral ions uptake reflected that $\mathrm{Na}^{+}$and $\mathrm{Cl}^{-}$ concentrations in the different plant parts (roots, stem and leaves) were almost doubled at the highest $\mathrm{NaCl}$ concentration, whereas both $\mathrm{K}^{+}$and $\mathrm{Ca}^{2+}$ were reduced by 24- $64 \%$ compared to control. At the highest $\mathrm{NaCl}$ concentration there was a tendency of higher concentration of $\mathrm{Na}^{+}$and $\mathrm{Cl}^{-}$and lower concentrations of $\mathrm{K}^{+}$and $\mathrm{Ca}^{2+}$ in the leaves. It could be concluded that 2-month moringa transplants might be $\mathrm{NaCl}$ tolerant up to $8 \mathrm{dSm}^{-1} \mathrm{Ec}$. Further studies are required to assess the mechanism of salinity tolerance of moringa. 2-month moringa transplants rather than direct seeding could be recommended for utilization of salt affected areas.
\end{abstract}

Keywords Early Growth, Moringa Oleifera, Sodium Chloride Tolerance, Toxic Ion Exclusion, 2-Month Old Transplants

\section{Introduction}

Among the 13 known species of the family Moringaceae, Moringa oleifera is an easily propagated shrub. It is originated in India and extended to most tropical countries (Africa, Asia and America). Its numerous economic uses (food, fodder medicines ...etc) together with its easy propagation have raised an international interest for it. It tolerates a wide range of soil condition but prefers a neutral to slightly acidic (PH 6.3 - 7) well drained sandy or loamy soils. It is considered as drought resistant but water logging sensitive (Suen, 2008).

Salinity problems affect agricultural production worldwide, especially in arid and semi arid regions and in coastal deserts. Most arable lands were considered unsuitable for farming due to salinity (Haffez 1993 and Davis 2000). The salt tolerance of certain crops varies with growth stages. Some crops are sensitive at germination but are tolerant at advanced growth stages. Follet et al. (1981) and Khan et al. (2009) reported a significant reduction of seedling growth (shoot and root length and shoot/root ratio) of four forest tree species. They recommended Acacia.ampliceps for saline soils followed by Acacia nilotica. Great reductions (50\%) in growth of seedlings of a number of forest tree species due to salinity were recorded by Sharma et al. (1992) and Shalan (1997), where a severe mortality of species tested was caused at a salinity level above $6.5 \mathrm{dS} / \mathrm{m}$. Tattini (1994);

Chartzoulakis et al. (2002) and Demural (2005) reported different seedling growth reductions of olive trees, showing that olive cultivars varied in their response to high salinity. The adverse effects of saline medium on different growth stages were attributed to either low water uptake due to low medium water potential (Mauromicale and Licardro, 2002) or certain ion $\left(\mathrm{Na}^{+}\right.$and $\left.\mathrm{Cl}^{-}\right)$toxicity (Flowers and Yeo, 1986) or both. Martin and Koebner (1995) and Werner (2003) reported that the reduction in plant growth by $\mathrm{NaCl}$ might be attributed to the inhibitory and toxic effects of ions mainly $\mathrm{Na}^{+}$and $\mathrm{Cl}^{-}$. Similar results were also obtained by Carter et al. (2005). They reported that greater $\mathrm{Cl}^{-}$amounts than that of $\mathrm{Na}^{+}$were accumulated at lower salinities. However, high concentrations of both were reported at higher salinities. This was also considered by Misra et al. (1996) and Alarcon et al. (1999) as a mechanism of salt tolerance where the roots avoid the toxic effects of ions by transporting them toward $\mathrm{s}$ the upper parts and thus maintain their growth. Glenn et al. (1999) and Munns (2002) suggested that salt tolerant plants may have a low rate of $\mathrm{Na}^{+}$and $\mathrm{Cl}^{-}$transport to leaves. Also 
they have the ability to compartmentalize these ions in vacuoles to prevent their buildup in the cytoplasm or cell walls and thus avoid salt toxicity. Accordingly, this study is objected to evaluate sodium chloride tolerance of moringa at early growth. Also how it can tolerate salinity.

\section{Materials and Methods}

This study was carried out in 2010 at the nursery of medicinal and aromatic plants, Department of Horticulture, College of Agricultural Studies, Sudan University of Science and Technology. The mean maximum and minimum temperatures were $36^{\circ} \mathrm{C}$ and $17^{\circ} \mathrm{C}$, respectively. Moringa seeds were obtained from Forestry Research Station, Soba, Agricultural Research Cooperation, Federal Ministry of Agriculture, Sudan. The soil used was a heavy clay soil having a $\mathrm{pH}$ of 7.5 and $1.8 \mathrm{dSm}^{-1} \mathrm{Ec}$. After its field capacity was recorded, the soil was packed in 16 plastic bags $(12 \times 20$ $\mathrm{cm})$. Each bag contained $8 \mathrm{~kg}$ of soil. Three different quantities of sodium chloride $(\mathrm{NaCl})$ as percentage of soil weight were added and thoroughly mixed with soil to have three different concentrations $\left(0.2,0.4\right.$ and $\left.0.8 \% \mathrm{ww}^{-1}\right)$ in addition to a control without $\mathrm{NaCl}(0.0 \%)$. The four $\mathrm{NaCl}$ concentrations in the soil solution had 1.8 (control), 4,8 and $16 \mathrm{dSm}^{-1}$ Ec. Two months old and of almost the same size moringa transplants were planted in the plastic bags (one plant/bag) containing four $\mathrm{NaCl}$ concentrations. Tap water was added to each bag every other day in almost equal quantities to keep the soil at the field capacity during the experiment.

The experimental units were distributed according to completely randomized design with four replications. The transplants growth was evaluated one month from planting as main stem height, number of leaves per plant, root length, fresh and dry weights of stems, leaves and roots and $\mathrm{K}^{+}, \mathrm{Na}^{+}$, $\mathrm{Ca}^{2+}$ ( after dry digestion using flame photometer) and $\mathrm{Cl}^{-}$(by titration) contents of stem, leaves and roots. The data collected were subjected to statistical analyses using the computer progamme (SAS ). Means were compared using the least significant difference test (LSD) at $\mathrm{P} \leq 0.05$ (Steel et al. 1997)

\section{Results}

As in Table1the stem height and number of leaves of young trees were only significantly reduced by the highest $\mathrm{NaCl}$ concentration $\left(0.8 \% \mathrm{NaCl}\right.$ or $\left.16 \mathrm{dSm}^{-1} \mathrm{Ec}\right)$. The reductions were $30 \%$ and $44 \%$ for height and number of leaves, respectively, compared to control .The root length was only slightly affected ( less than $30 \%$ ) by the different $\mathrm{NaCl}$ concentrations. The same effects (Table2) were also reflected on fresh weights of stems and leaves but not of the roots. The reductions of both were $62 \%$ at the highest concentration compared to control. Only the dry weight of leaves was significantly affected ( $40 \%$ reduction) by the highest concentration.

Table1. Effect of $\mathrm{NaCl}$ on growth (stem height, root length and number of leaves) of two months old moringa transplants

\begin{tabular}{cccc}
\hline NaCl concentration (\% w/w of soil ) & Transplant height (cm) & No. of Leaves/plant & Root length (cm) \\
\hline Control (0 \%) & $49.6^{\mathrm{ab}}$ & $10.6^{\mathrm{a}}$ & $8.9^{\mathrm{a}}$ \\
$0.2 \%$ & $40.5^{\mathrm{bc}}$ & $9.2^{\mathrm{a}}$ & $7.1^{\mathrm{a}}$ \\
$0.4 \%$ & $50.9^{\mathrm{a}}$ & $9.3^{\mathrm{a}}$ & $6.9^{\mathrm{a}}$ \\
$0.8 \%$ & $34.9^{\mathrm{c}}$ & $8.5^{\mathrm{a}}$ & $6.0^{\mathrm{a}}$ \\
\hline
\end{tabular}

Means followed by the same letters are not significantly different using LSD at $\mathrm{P} \leq 0.05$.

Table2. Effect of $\mathrm{NaCl}$ on fresh and dry weights of stems, leaves, and roots of two months old moringa transplants

\begin{tabular}{|c|c|c|c|c|c|c|}
\hline \multirow{2}{*}{$\begin{array}{l}\mathrm{NaCl} \text { concentration } \\
(\% \mathrm{w} / \text { wof soil })\end{array}$} & \multicolumn{3}{|c|}{ Fresh weight (g) } & \multicolumn{3}{|c|}{ Dry weight (g) } \\
\hline & Stems & Leaves & Roots & Stems & Leaves & Roots \\
\hline Control $(0 \%)$ & $34.2^{\mathrm{a}}$ & $13.4^{\mathrm{a}}$ & $17.5^{\mathrm{a}}$ & $6.4^{\mathrm{a}}$ & $5.5^{\mathrm{a}}$ & $3.4^{\mathrm{a}}$ \\
\hline $0.2 \%$ & $22.8^{\mathrm{b}}$ & $8.4^{\mathrm{b}}$ & $17.0^{\mathrm{a}}$ & $5.4^{\mathrm{a}}$ & $4.3^{b c}$ & $3.2^{\mathrm{a}}$ \\
\hline $0.4 \%$ & $23.6^{\mathrm{b}}$ & $8.4^{\mathrm{b}}$ & $17.2^{\mathrm{a}}$ & $5.5^{\mathrm{a}}$ & $4.6^{\mathrm{ab}}$ & $3.6^{\mathrm{a}}$ \\
\hline $0.8 \%$ & $13.0^{\mathrm{c}}$ & $5.2^{\mathrm{b}}$ & $14.8^{\mathrm{a}}$ & $3.4^{\mathrm{a}}$ & $3.3^{\mathrm{c}}$ & $3.2^{\mathrm{a}}$ \\
\hline
\end{tabular}

Means followed by the same letters are not significantly different using LSD at $\mathrm{P} \leq 0.05$. 
Table3. Effect of $\mathrm{NaCl}$ on $\mathrm{Na}^{+}, \mathrm{K}^{+}, \mathrm{Cl}^{-}$, and $\mathrm{Ca}^{2+}$ concentrations in the roots of two months old moringa transplants

\begin{tabular}{|c|c|c|c|c|}
\hline \multirow{2}{*}{$\begin{array}{c}\mathrm{NaCl} \text { concentration } \\
(\% \mathrm{w} / \mathrm{w} \text { of soil })\end{array}$} & \multicolumn{4}{|c|}{ Mineral ion concentration $(\mathrm{mg} / \mathrm{g} \mathrm{dm})$} \\
\hline & $\mathrm{Na}^{+}$ & $\mathrm{K}^{+}$ & $\mathrm{Ca}^{+2}$ & $\mathrm{Cl}^{-}$ \\
\hline Control $(0 \%)$ & $19.3^{\mathrm{c}}$ & $17.4^{\mathrm{a}}$ & $11.0^{\mathrm{a}}$ & $31.6^{\mathrm{c}}$ \\
\hline $0.2 \%$ & $24.4^{\mathrm{b}}$ & $15.2^{\mathrm{b}}$ & $9.5^{b}$ & $42.0^{\mathrm{b}}$ \\
\hline $0.4 \%$ & $27.2^{\mathrm{b}}$ & $14.2^{\mathrm{b}}$ & $8.0^{\mathrm{c}}$ & $48.5^{\mathrm{b}}$ \\
\hline $0.8 \%$ & $31.9^{\mathrm{a}}$ & $11.6^{\mathrm{c}}$ & $7.0^{\mathrm{c}}$ & $63.1^{\mathrm{a}}$ \\
\hline
\end{tabular}

Means followed by the same letters are not significantly different using LSD at $\mathrm{P} \leq 0.05$.

Table4. Effect of $\mathrm{NaCl}$ on $\mathrm{Na}^{+}, \mathrm{K}^{+}, \mathrm{Cl}^{-}$, and $\mathrm{Ca}^{2+}$ concentrations in the stems and leaves of two months old moringa transplants

\begin{tabular}{ccccccccc}
\hline $\begin{array}{c}\text { NaCl concentration } \\
(\% \text { w/w of soil })\end{array}$ & \multicolumn{9}{c}{ Mineral ion concentration(mg/g dm) } \\
& $\mathrm{Na}^{+}$ & $\mathrm{K}^{+}$ & $\mathrm{Ca}^{+2}$ & $\mathrm{Cl}^{-}$ & $\mathrm{Na}^{+}$ & $\mathrm{K}^{+}$ & $\mathrm{Ca}^{+}$ & $\mathrm{Cl}^{-}$ \\
\hline Control $(0 \%)$ & $13.7^{\mathrm{b}}$ & $19.5^{\mathrm{a}}$ & $17.8^{\mathrm{a}}$ & $31.3^{\mathrm{b}}$ & $12.2^{\mathrm{c}}$ & $28.9^{\mathrm{a}}$ & $28.3^{\mathrm{a}}$ & $64.1^{\mathrm{b}}$ \\
$0.2 \%$ & $17.4^{\mathrm{b}}$ & $17.4^{\mathrm{b}}$ & $14.5^{\mathrm{b}}$ & $42.0^{\mathrm{b}}$ & $20.4^{\mathrm{b}}$ & $24.7^{\mathrm{b}}$ & $22.5^{\mathrm{ab}}$ & $75.0^{\mathrm{c}}$ \\
$0.4 \%$ & $20.5^{\mathrm{b}}$ & $16.9^{\mathrm{b}}$ & $13.5^{\mathrm{bc}}$ & $46.2^{\mathrm{a}}$ & $26.1^{\mathrm{ab}}$ & $20.8^{\mathrm{c}}$ & $18.4^{\mathrm{bc}}$ & $121.7^{\mathrm{b}}$ \\
$0.8 \%$ & $28.5^{\mathrm{a}}$ & $14.9^{\mathrm{c}}$ & $11,9^{\mathrm{c}}$ & $67.2^{\mathrm{a}}$ & $32.7^{\mathrm{a}}$ & $10.5^{\mathrm{d}}$ & $14.3^{\mathrm{c}}$ & $137.0^{\mathrm{a}}$ \\
\hline
\end{tabular}

Mineral ions uptake (Table3) reflected that $\mathrm{Na}^{+}$and $\mathrm{Cl}^{-}$ concentrations in the roots were increased with increased $\mathrm{NaCl}$ concentrations.. Their concentrations were 1.5 and twice higher at the highest concentration compared to control. Also both $\mathrm{K}^{+}$and.Ca ${ }^{2+}$ concentrations were reduced by $30 \%$ and $40 \%$, respectively. Almost the same was observed for the four mineral ions concentrations in stem and leaves (Table4). The concentrations of both $\mathrm{Na}^{+}$and $\mathrm{Cl}^{-}$were almost doubled in both parts at the highest $\mathrm{NaCl}$ concentrations. Both $\mathrm{K}^{+}$and $\mathrm{Ca}^{2+}$ concentrations were reduced by $24 \%$ and $34 \%$ in the stem and $64 \%$ and $50 \%$ in the leaves, respectively.

At the highest $\mathrm{NaCl}$ concentration there was a tendency of higher concentration of $\mathrm{Na}^{+}\left(28.5 \mathrm{mgg}^{-1}\right.$ dry matter " $\mathrm{dm}$ " ) and $\mathrm{Cl}^{-}\left(67.1 \mathrm{mgg}^{-1} \mathrm{dm}\right)$ and lower concentrations of $\mathrm{K}^{+}$ $\left(14.9 \mathrm{mgg}^{-1} \mathrm{dm}\right)$ and $\mathrm{Ca}^{2+}\left(11.9 \mathrm{mgg}^{-1} \mathrm{dm}\right)$ in the leaves. The accumulation of $\mathrm{Cl}^{-}\left(67.1 \mathrm{mgg}^{-1} \mathrm{dm}\right)$ in the leaves was higher than that of $\mathrm{Na}^{+}\left(28.5 \mathrm{mgg}^{-1} \mathrm{dm}\right)$.

\section{Discussion}

All transplant growth parameters were negatively affected with increased $\mathrm{NaCl}$ concentration. The reduction of plant height, number of leaves and stem and leaves fresh weights were significant at the highest $\mathrm{NaCl}$ concentration $(0.8 \%$ $\mathrm{NaCl})$. The reduction was $30 \%, 44 \%$ and $62 \%$ for transplant height, number of leaves and stem and leaves fresh weights, respectively, compared to control. The root growth was less affected. Similar results were obtained by Hussain and
Rehman (1997). They concluded that the roots of plants were more tolerant than the shoots. The reduction of growth was reflected by the fresh weight rather than the dry weight of the plant parts. Also Demir and Arif (2003) showed that the root growth of safflower was less adversely affected by salinity compared to shoot growth. Moreover, Jamil (2004) reported that salt stress inhibited plant growth (shoot and root length and shoot and root fresh weights). The first reduction in plant growth may be attributed to initial sudden increase of osmotic pressure as stated by Hajibagheri (1989), suggesting that high salinity might inhibit root and shoot elongation due to slowing down of water uptake by the plant. 2- month old moringa trees could tolerate that effect without further reduction of growth except at the highest $\mathrm{NaCl}$ concentration $(0.8 \%)$.

However, Martin and Koebner (1995) and Werner (2003) reported that the reduction in plant growth by $\mathrm{NaCl}$ might be attributed to the inhibitory effects of toxic ions mainly $\mathrm{Na}^{+}$ and $\mathrm{Cl}^{-}$. The same was reflected by the results, where there was a tendency of increased $\mathrm{Na}^{+}$and $\mathrm{Cl}^{-}$concentrations and reduced $\mathrm{K}^{+}$and $\mathrm{Ca}^{2+}$ in all transplant parts with increased $\mathrm{NaCl}$ concentrations. Their concentrations were almost doubled at the highest $\mathrm{NaCl}$ concentrations compared to control. However, the leaves showed the highest concentrations of both $\mathrm{Na}^{+}$and $\mathrm{Cl}^{-}$and the lowest ones of both $\mathrm{K}^{+}$and $\mathrm{Ca}^{2+}$. Similar results were shown by Carter et al. (2005). They found that as salinity increased leaf $\mathrm{Cl}^{-}$and $\mathrm{Na}^{+}$ of $L$. perezii increased.. They concluded that plants accumulated a greater amount of $\mathrm{Cl}^{-}$than $\mathrm{Na}^{+}$at lower salinities but high concentration of both at higher ones. 
Imamul Huq (1984) found that salt tolerance or possibility to adjust to highly cellular concentration of $\mathrm{Na}^{+}$was always accompanied by a decrease in the concentration of $\mathrm{K}^{+}$and $\mathrm{Ca}^{2+}$ and an increase of $\mathrm{Mg}^{2+}$. As shown by the assessment of the plant growth moringa trees could be considered tolerant to higher $\mathrm{NaCl}$ concentrations up to $0.4 \%$ or $8 \mathrm{dS} / \mathrm{m} \mathrm{Ec}$. This tolerance could be attributed to its ability to restrict the transport of toxic

$\mathrm{Na}^{+}$and $\mathrm{Cl}^{-}$to the shoot at lower $\mathrm{NaCl}$ concentration and accumulation of them in the older leave and branches at higher ones to get rid of them by considerable shedding of older leaves and branches. This was also considered by Misra et al. (1996) and Alarcon et al. (1999) as a mechanism of salt tolerance where the roots avoid the toxic effects of ions by transporting them towards upper parts and thus maintain their growth. Flowers and Yeo (1986), Glenn et al. (1999) and Munns (2002) suggested that salt tolerant plants may have a low rate of $\mathrm{Na}^{+}$and $\mathrm{Cl}^{-}$transport to leaves and have the ability to compartmentalize these ions in vacuoles to prevent their buildup in cytoplasm or cell walls and thus avoid salt toxicity. It could be concluded that young moringa trees (2- month or perhaps older) were less affected by $\mathrm{NaCl}$ concentrations up to $0.4 \%$ or $8 \mathrm{dSm}^{-1} \mathrm{Ec}$ showing that moringa trees at that age or growth stage might be tolerant to $\mathrm{NaCl}$ concentrations of $8 \mathrm{dSm}^{-1}$. Like other glycophytes it might avoid salt toxicity by having low rate of $\mathrm{Na}^{+}$and $\mathrm{Cl}^{-}$ transport to the leaves or their compartment in the vacuoles to prevent their buildup in the cytoplasm or cell walls and thus avoid salt toxicity. However, further field studies on saline soils and on the higher accumulation of toxic ions $\left(\mathrm{Na}^{+}\right.$ and $\mathrm{Cl}^{-}$) in the older and their restricted translocation to the younger parts of moringa are required. However, it could be concluded that moringa transplants are $\mathrm{NaCl}$ up to 8 $\mathrm{dSm}^{-1} \mathrm{Ec}$. The mechanism of salinity tolerance of moringa might be the avoidance of toxic ions. Further studies are required to assess mineral ion $\left(\mathrm{Na}^{+}, \mathrm{Cl}^{-}, \mathrm{K}^{+}\right.$and $\left.\mathrm{Ca}^{2+}\right)$ concentration in the young and old moringa leaves and their transportation and accumulation in the different plant parts. 2-month moringa transplants than direct seeding could be recommended for the utilization of salinity affected areas.

\section{REFERENCES}

[1] Alarcon, J..J., Morales, M.A., Torrecillas, A. and Sanchez-Blango, M. J. (1999). Growth, water relations and accumulation of organic and inorganic solutes in the halophytes Limonium latifolium cv. avignon and its interspecific hybrid Limonium caspia $X$ Limonium latifolium cv. bettlaard during salt stress. Journal of Plant Physiology, 154: 795-801

[2] Carter, C.T., Grieve C.M. and Poss, J.A. (2005). Salinity effects on emergence, survival and ion accumulation of Limonium perezii. Journal of. Plant Nutrition., 28: $1243-1257$

[3] Chartzoulakis, K. M., Loupassaki, M. B. and Androulakis, I.
2002. Effects of $\mathrm{NaCl}$ salinity on growth, ion content and carbon dioxide assimilation rate of six olive cultivars. Scientia Horticulturae 96: 235-247.

[4] Demir, M., and Arif I. 2003. Effects of different soil salinity levels on germination and seedling growth of safflower (Carthamus tinctorius.), Turkish Journal Agriculture and Forestry 27: 221-227.

[5] Demural, M. A. (2005). Comparative response of two olive. (Olea europaea L.) cultivars to salinity. Turskish Journal of Agriculture and.Forestry 29: 267-274

[6] Flowers, T.J. and Yeo. A.R. 1986. Ion relations of plants under drought and salinity. Australian Journal of Plant Physiology 13: 75-91.

[7] Follet, R. H. Larry, S. M. and Roy L. D. 1981. Fertilizers and Soil Amendments. 6th Edn., Prentice-Hall, inc., Englewood Cliffs, USA. PP 557

[8] Glenn, E.P., Brown, J.J. and Blumwald. E. 1999. Salt tolerance and crop potential of halophytes. Critical Review of Plant Science 18: 227-255.

[9] Hafeez, S. M. 1993. Identification of fast growing salt tolerant tree species. Pakistan Journal of Forestry 43 (4): 216- 220

[10] Hajibagheri, M.A., Yeo, A. R., Flowers, T. .J., and Collins, J.C. 1989. Salinity resistance in $Z$ ea mays fluxes of potassium, sodium and chloride, cytoplasmic concentrations and microsomal membrane lipids, Plant, Cell and Environment 12: 753-757.

[11] Hussain M. K., and Rehman, O.U. 1997. Evaluation of sunflower (Helianthus annuus L.) germplasm for salt tolerance at the shoot stage. Helia 20: 69-78

[12] Imamul-Huq. S. M. 1984. Comparison de la resistance stress saline de Vigna sinensis. PhD. Thesis, University of Nancy, France.

[13] Jamil, M., Lee, D. B. Jung, K. Y., Ashraf, M., Lee, S. C., and Rhao, E. S. 2006. Effect of salt $(\mathrm{NaCl})$ stress on germination and early seedling growth of four vegetable species. Journal of Central European Agriculture 2: 273-282

[14] Khan, G. S., Khan, Z. H,. Imran,J., Quraishi,M. U., Yaqoob, S., and Khan, S. H. 2009. Effect of salinity on germination and growth of some forest tree species at seedling growth. Journal of Agricultural Research 47(3): 271-279

[15] Martin, P. K .and Koebner. 1995. Sodium and chloride ions contribute synergistically to salt toxicity in wheat. Biologia Plantarum 37: 265-271

[16] Misra, A. N., Murmu, P. B. Singh, S. and Misra. M. 1996. Growth and proline accumulation in mung bean seedlings as affected by sodium chloride. Biologia Plantarum 38: 531-536.

[17] Munns, R. 2002. Comparative physiology of salt and water stress. Plant Cell and Environment 25: 239- 250.

[18] Shallan, A. H., 1997. Effect of salinity on germination and juvenile development of

[19] some forest tree species. M. Sc. Thesis, Facaulty of Forestry, University of Khartoum, Sudan PP. 74

[20] Sharma, S. D., Prasad, K. G. and Singh H.B. 1992. Salinity 
and alkalinity tolerance of some leguminous trees seedlings. Van - Vagina 30 (2):. 86- 94. Steel, R.G.D., Torrie, J. H. and Dickie, D. A. 1997. Principles and Procedures of Statistics. 3rd. Edn. Mc Graw Hill Book Co., New York, USA, PP 666

[21] Suein, W. A. 2008. Moringa oleifera climate, using Moinga oleifera as a source for biodiesel from "Production of biodiesel from perennials " A report by Deptartment. of
Agriculture and Food, Government of Western Australia.

[22] Tattini, M. 1994. Ionic relations of aeroponically-grown olive genotypes, during salt stress. Plant and Soil 161: 251-256.

[23] Werner, J. E., and Finkelstein, R.R. 1995. Arabidopsis mutants with reduced response to $\mathrm{NaCl}$ and osmotic stress, Physiologia Plantarum 93: 659-666. 